\title{
Hiperurisemia Dan Cystatin C
}

\author{
Meri $^{1}$, Yane Liswanti ${ }^{2}$ \\ 1,2 Prodi D-III Analis Kesehatan, STIKes BTH Tasikmalaya, Indonesia
}

\begin{tabular}{|c|c|}
\hline Article Info & ABSTRACT \\
\hline Article history: & $\begin{array}{l}\text { Hyperuricemia is a state of increased uric acid levels in the blood. } \\
\text { Increased uric acid levels can cause disease, one of which is a kidney }\end{array}$ \\
\hline Received Des 08 ${ }^{\text {th }}, 2019$ & disorder. Cystatin C parameter is used as a parameter that is superior \\
\hline Revised Jan $23^{\text {th }}, 2020$ & to creatinine in assessing kidney function. The condition of the kidneys \\
\hline Accepted Jan $26^{\text {th }}, 2020$ & $\begin{array}{l}\text { that are hyperuricemia still cannot be explained completely, so } \\
\text { cystatin } C \text { examination is done to measure kidney function due to }\end{array}$ \\
\hline Keyword: & $\begin{array}{l}\text { hyperuricemia. The purpose of this study is to determine the picture of } \\
\text { cystatin } C \text { in hyperuricemia. The research method is descriptive. }\end{array}$ \\
\hline Hyperuricemia & Participants in this study were men aged $18-65$ years (25 people) \\
\hline Cystatin $C$ & according to the criteria of hyperuricemia, fasting, not obese. Results: \\
\hline Kidney Function & $\begin{array}{l}\text { Uric acid (mean) }=8,928 \mathrm{mg} / \mathrm{dL} \text { and Cystatin } C(\text { mean })=1.08 \mathrm{mg} / \\
d L . \text { Uric acid levels are above the normal value (hyperuricemia) } \\
\text { because the normal value is } 3.4-7.0 \mathrm{mg} / d \mathrm{~L} . \text { At these levels cystatin C } \\
\text { examination was carried out which had elevated levels above normal } \\
\text { values. Conclusion: The picture of increased uric acid has an } \\
\text { increased picture of cystatin C. }\end{array}$ \\
\hline
\end{tabular}

Copyright $\odot$ Jurnal Analis Medika Bio Sains All rights reserved.

\begin{abstract}
ABSTRAK
Hiperurisemia merupakan keadaan kadar asam meningkat dalam darah. Kadarnya yang meningkat dapat menyebabkan penyakit, salah satunya yaitu adalah gangguan ginjal. Parameter cystatin C dipakai sebagai parameter yang lebih unggul dibanding kreatinin dalam menilai fungsi ginjal. Kondisi ginjal yang sedang hiperurisemia masih belum dapat dijelaskan secara lengkap, dengan demikian dilakukan pemeriksaan cystatin $\mathrm{C}$ untuk mengukur fungsi ginjal akibat hiperurisemia. Tujuan penelitian yaitu untuk mengetahui gambaran cystatin $\mathrm{C}$ pada hiperurisemia. Metode penelitian yaitu deskriptif. Partisipan pada penelitian ini adalah lakilaki berusia 18-65 tahun (25 orang) sesuai kriteria yaitu hiperurisemia, berpuasa, tidak obesitas. Hasil penelitian : kadar asam urat $($ mean $)=8,928 \mathrm{mg} / \mathrm{dL}$ dan Cystatin $\mathrm{C}($ mean $)=1,08 \mathrm{mg} / \mathrm{dL}$. Kadar asam urat tersebut berada diatas nilai normal (hiperurisemia) karena nilai normalnya adalah 3,4-7,0 mg/dL. Pada kadar tersebut diakukan pemeriksaan cystatin $\mathrm{C}$ yang memiliki kadar peningkatan diatas nilai normal. Kesimpulan: gambaran asam urat meningkat memiliki kadar cystatin $\mathrm{C}$ yang meningkat.
\end{abstract}

Kata Kunci: Hiperurisemia, Cystatin C, Fungsi ginjal

Copyright $\odot$ Jurnal Analis Medika Bio Sains

\section{Pendahuluan}

Hiperurisemia merupakan kondisi meningkatnya kadar asam urat dalam darah. Asam urat adalah hasil katabolisme purine(Verdiansah, 2016). Kadar asam urat dapat meningkat oleh karena adanya ketidakseimbangan antara produksi dan eksresi. Peningkatan kadar tersebut dapat dikaitkan dengan kejadian penyakit, salah satunya adalah penyakit ginjal. Secara klinis hiperurisemia memiliki makna yang cukup penting oleh karena dapat menyebabkan nefropaati asam urat, artritis pirai, tofi, dan nefrolitiatis(Manampiring, 2011). 
Fungsi ginjal yang mengalami gangguan oleh kemungkinan yang disebabkan hiperurisemia dapat di deteksi dengan menggunakan parameter cystatin C. Parameter ini memiliki keunggulan yaitu lebih akurat dibandingkan dengan parameter kreatinin. Pemeriksaan kreatinin masih dapat mengalami gangguan dari kondisi metabolisme protein, terutama pada kasus obesitas, sirosis hati dan malnutrisi(Verdiansah, 2016). Cystatin C sangat berlimpah dalam serum atau plasma dan dengan mudah disaring oleh glomerulus. Pada kondisi fungsi ginjal menurun, maka akan terdeteksi dengan meningkatnya kadar cystatn C. Kadar cystatin C dalam serum jauh lebih kecil kemungkinannya untuk dipengaruhi oleh faktor-faktor seperti jenis kelamin, status metabolisme atau keadaan penyakit daripada kadar kreatinin(Prozialeck et al., 2016), sehingga dalam menggambarkan kadar hiperurisemia yang dapat menimbulkan penurunan fungsi ginjal adalah dengan menggunakan parameter cystatin C. Hasil penelitian diharapkan dapat memberikan gambaran kadar hiperurisemia dengan kadar cystatin $\mathrm{C}$, dimana parameter tersebut dapat memberikan sedikit gambaran mengenai fungsi ginjal.

Peneliti bermaksud untuk mengetahui gambaran kadar hiperuricemia dan kadar cystatin C. Dengan demikian kadar cystatin $\mathrm{C}$ dapat dipergunakan sebagai parameter yang menggambarkan kondisi fungsi ginjal akibat hiperurisemia. Tetapi, dalam mendiagnosa terhadap fungsi ginjal pun diperlukan parameter lain yang saling melengkapi, tidak hanya melakukan pemeriksaan darah.

\section{Metode Penelitian}

Penelitan ini merupakan penelitian deskriptif. Penelitian dilakukan pada bulan Maret-Juni 2019 di Rumah Sakit Jasa Kartini, Laboratorium STIKes BTH Tasikmalaya dan Laboratorium Klinik Prodia. Partisipan yang menjadi subjek penelitian adalah sebanyak 188 orang yang berusia 18-65 tahun. Pengambilan sampel dilakukan secara purposive sampling, dengan melihat kriteria inklusi dan ekslusi dan diperoleh sebanyak 25 orang.Kriteria inklusi yang dipakai yaitu berpuasa, hiperurisemia dan tidak obesitas. Penelaahan protokol penelitian sudah memiliki persetujuan dari komite etik STIKes BTH Tasikmalaya. Alat dan bahan yang digunakan adalah torniquet, plester, kapas alkohol, spuit, tabung serum, centronorm, aquabidest, reagen asam urat (PT. AIM), mikropipet, easy touch digital, stik asam urat dan fotometer TC 3300. Relawan yang sudah berpuasa diperiksa kadar asam urat dan diukur IMT, kemudian jika memenuhi kriteria inklusi dilakukan pemeriksaan kadar asam urat menggunakan alat fotometer TC 3300 yaitu sebagai berikut : a) Masukan reagen asam urat ke dalam 4 tabung reaksi, masing-masing sebanyak $1000 \mu$ l. b) Tambahkan $20 \mu 1$ standard, $20 \mu 1$ serum control, $20 \mu \mathrm{l}$ aquades, dan 20 ul serum sampel ke dalam setiap tabung secara berurutan. C) Homogenkan kemudian diinkubasi selama 5 menit pada suhu $37^{\circ} \mathrm{C}$, kemudian dibaca menggunakan fotometer (Meri \& Liswanti, 2019).

Kadar Cystatin C diperiksa dengan menggunakan metode imunonephelometry yaitu metode Particleenhanced immunonephelometry (PENIA) yang memiliki prinsip yaitu partikel polystyrene yang telah dilapisi oleh antibodi CysC akan mengalami aglutinasi pada saat direaksikan dengan sampel serum yang mengandung CysC. Banyaknya pancaran cahaya atau scattered light yang diperiksa setara dengan jumlah konsentrasi jumlah CysC dalam sampel (Yaswir \& Maiyesi, 2012). Pemeriksaan sampel dilakukan dengan memasukan sampel yang telah diencerkan sebanyak 1:100 menggunakan alat secara otomatis (Siemens) yang selanjutnya sampel akan dibaca oleh alat (Siemens, 2011). Hasil yang keluar adalah berupa angka dengan interpretasi hasil untuk laki-laki yaitu $0,56-0,98 \mathrm{mg} / \mathrm{dl}$ (Prodia). Data hasil penelitian dianalisis SPSS 25 distribusi frekuensi. Data ditampilkan dalam bentuk tabel yang berisi nilai mean atau rata-rata dan simpangan deviasi sebagai distribusi frekuensi.

\section{Hasil Penelitian dan Pembahasan}

Hasil analisis dan pengujian hipotesis dapat disajikan berupa grafik atau tabel untuk memperjelas secara verbal. Tabel dan gambar dapat menggunakan angka 1,2,3, dan seterusnya. Jumlah tabel dan gambar maksimal 5. Judul tabel berada diatas, sedangkan judul gambar ada di bawah. 
Tabel 1 Gambaran Rata-Rata Kadar Asam Urat dan Kadar Cystatin C

Sampel diperoleh sebanyak 25 orang dengan karakteristik sebagai berikut :

\begin{tabular}{|c|c|c|c|c|}
\hline Variabel & $\begin{array}{c}\text { Usia } \\
\text { (Tahun) }\end{array}$ & IMT & $\begin{array}{c}\text { Kadar } \\
\text { Asam Urat } \\
(\mathrm{mg} / \mathrm{dL})\end{array}$ & $\begin{array}{c}\text { Kadar } \\
\text { Cystatin C } \\
(\mathrm{mg} / \mathrm{dL})\end{array}$ \\
\hline Mean & 43,44 & 24,04 & 8,928 & 1,0800 \\
\hline $\begin{array}{c}\text { Standar } \\
\text { Deviasi }\end{array}$ & 9,134 & 3,102 & 1,0450 & 0,17642 \\
\hline $\begin{array}{c}\text { Jumlah } \\
\text { sampel }\end{array}$ & 25 & 25 & 25 & 25 \\
\hline
\end{tabular}

Berdasarkan tabel 1, diperoleh informasi bahwa kadar asam urat partisipan mengalami peningkatan yaitu ratarata $8,928 \mathrm{mg} / \mathrm{dl}$ dan memiliki kadar cystatin $\mathrm{C}$ yang meningkat yaitu $1,08 \mathrm{mg} / \mathrm{dl}$. Nilai normal kadar asam urat untuk laki-laki adalah 3,4-7,0 mg/dL. Partisipan tidak termasuk obesitas, rata-rata IMT adalah 24,04 SD $\pm 3,102$.

Asam urat dalam tubuh difiltrasi oleh bagian ginjal yaitu oleh bagian glomerulus dan disekresikan oleh tubulus proksimal ke dalam urine. Sebagian besar direabsorpi ke dalam tubulus proksimal. Kadarnya yang meningkat akan menyebabkan peyimpanan dipersendian dan jaringan sehingga dapat menimbulkan inflamasi(Verdiansah, 2016).

Inflamasi terjadi oleh karena assam urat dianggap sebagai sinyal bahaya(Ramadan et al., 2017) oleh selsel imun dalam tubuh terutama oleh sel neutrofil dan makrofag menghasilkan berbagai sitokin inflamasi seperti interleukin $1 \beta$ (IL1 $\beta$ ), IL6(Di et al., 2017), tumor necrosis factor (TNF)(Ruggiero et al., 2006) dan lain-lain. Pengenalan oleh sel-sel imun terhadap asam urat dapat mengeluarkan nitrit oksida yang mampu menyebabkan degradasi tulang rawan(Liu-bryan et al., 2019) yang menyebabkan partisipan mengalami rasa sakit pada bagian persendian. Beberapa sel tersebut adalah sel neutrofil dan makrofag. Sel akan mengenali asam urat dan mengeluarkan berbagai sitokin sebagai respon adanya inflamasi.

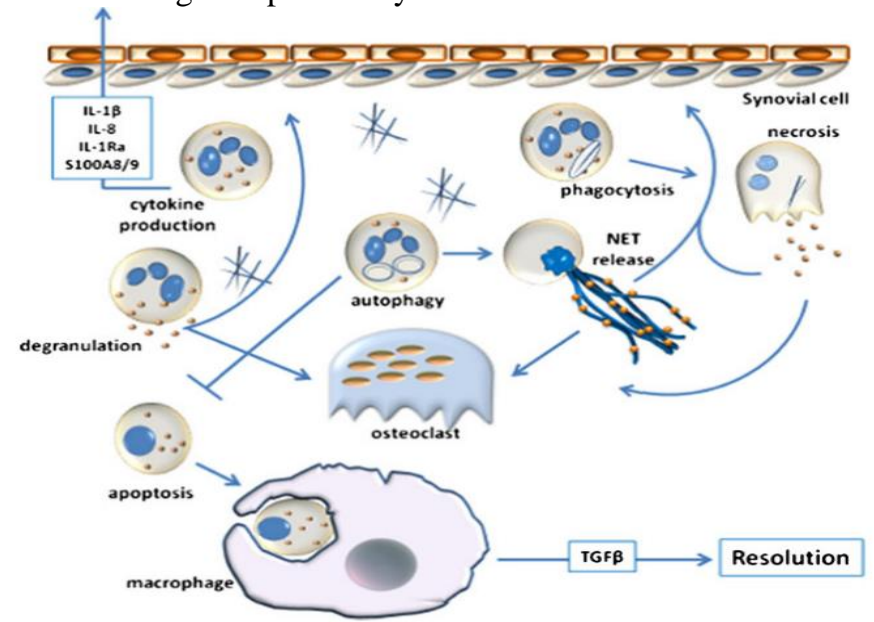

Gambar 1. Aktivasi Neutrofil oleh Kristal Asam Urat

Nitrit oksida tersebut merupakan salah satu derivat oksigen radikal, selain ion $\mathrm{OH}$, superoksida, dan peroxil yang menjadi sumber dari ROS atau radikal bebas. ROS dapat mengganggu homeostatis atau merangsang pertumbuhan sel tergantung pada kadar ROS yang dihasilkan (Elahi et al., 2009) Kerusakan jaringan oleh akibat ROS dinamakan oksidatif stress. 


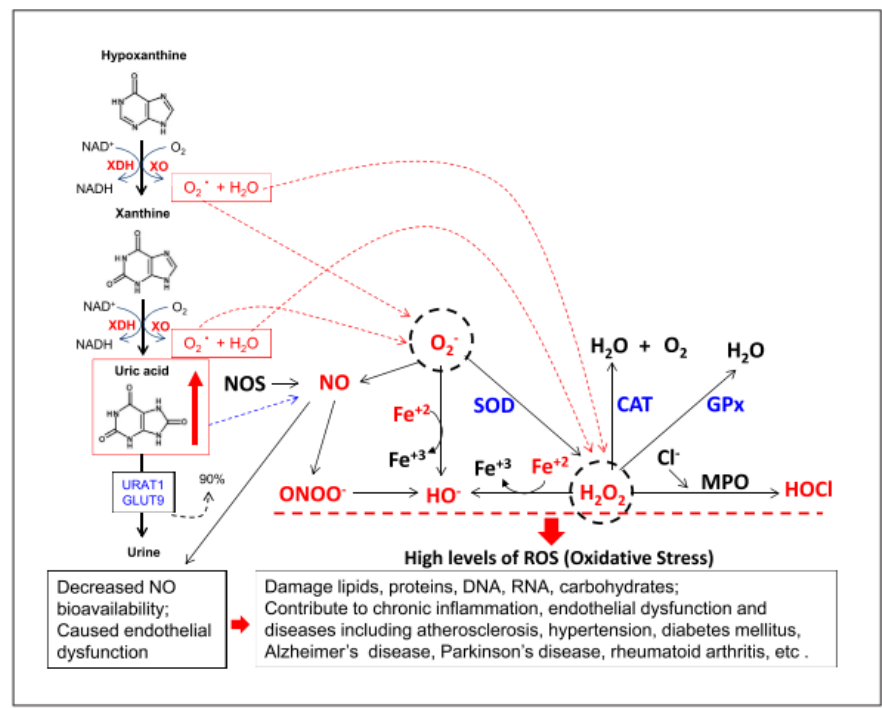

Gambar 2. Hiperurisemia dan oksidative stress

Kerusakan ginjal dapat diketahui dengan melakukan pemeriksaan laboratorium. Pemeriksaan yang dianggap unggul dibandingkan dengan kreatinin adalah Cystatin C(Prozialeck et al., 2016). Cystatin C ini terdapat pada semua sel. Pada keadaan ginjal mengalami gangguan, maka cystatin $\mathrm{C}$ akan memberikan gambaran keadaan fugsi ginjal.

Pada keadaan hiperurisemia dengan rata-rata $8,928 \mathrm{mg} / \mathrm{dl}$ ternyata memiliki kadar cystatin $\mathrm{C}$ yang mengalami peningkatan yaitu rata-rata $1,080 \mathrm{mg} / \mathrm{dL}$. Nilai normal cystatin $\mathrm{C}$ untuk laki-laki adalah $0,56-0,98 \mathrm{mg} / \mathrm{dL}$ (Prodia). Hal tersebut menunjukan adanya gangguan fungsi ginjal yang disebabkan oleh kondisi hiperurisemia. Pada penelitian ini memiliki keterbatasan yaitu dalam mencari sampel dengan kriteria inklusi terutama dalam memisahkan peserta yang kadar asam uratnya meningkat. Selain itu, pemeriksaan lain yang mendukung atau melengkapi terhadap fungsi ginjal tidak dilakukan (LFG, urine rutin dan sedimen serta mikroalbumin), dikarenakan keterbatasan dana.

\section{Kesimpulan}

Gambaran kadar asam urat yang meningkat (Hiperurisemia) pada nilai rata-rata $8,928 \mathrm{mg} / \mathrm{dL}$ memiliki gambaran kadar cystatin $\mathrm{C}$ yang meningkat yaitu $1,08 \mathrm{mg} / \mathrm{dl}$.

\section{Daftar Pustaka}

Di, Y., Wang, J., Chen, Y., Sun, N., Wu, L., \& Dai, X. (2017). Elevated Interleukin $1 \beta$ and Interleukin 6 Levels in the Serum of Children With Hyperuricemia. 00(00), 1-5. https://doi.org/10.1097/RHU.0000000000000611

Elahi, M. M., Kong, Y. X., \& Matata, B. M. (2009). Oxidative stress as a mediator of cardiovascular disease. December, 259-269.

Liu-bryan, R., Pritzker, K., Firestein, G. S., Terkeltaub, R., Liu-bryan, R., Pritzker, K., Firestein, G. S., \& Terkeltaub, R. (2019). TLR2 Signaling in Chondrocytes Drives Calcium Pyrophosphate Dihydrate and Monosodium Urate Crystal-Induced Nitric Oxide Generation. The Journal of Immunology. https://doi.org/10.4049/jimmunol.174.8.5016

Manampiring, A. E. (2011). Hiperurisemia dan respons imun. Jurnal Biomedik, 3(2), 102-110.

Meri, \& Liswanti, Y. (2019). Jumlah Neutrofil Absolut, Cystatin-C , dan Hiperurisemia (pp. 1-111). Sadari.

Prozialeck, W. C., VanDreel, A., Ackerman, C. D., Stock, I., Papaeliou, A., Yasmine, C., Wilson, K., Lamar, 
P. C., Sears, V. L., Gasiorowski, J. Z., Dinovo, K. M., Vaidya, V. S., \& Edwards, J. R. (2016).

Evaluation of cystatin $\mathrm{C}$ as an early biomarker of cadmium nephrotoxicity in the rat. BioMetals, 29(1), 131-146. https://doi.org/10.1007/s10534-015-9903-3

Ramadan, A., Land, W. G., \& Paczesny, S. (2017). Editorial: Danger signals triggering immune response and inflammation. Frontiers in Immunology, 8(AUG), 1-3. https://doi.org/10.3389/fimmu.2017.00979

Ruggiero, C., Cherubini, A., Ble, A., Bos, A. J. G., Maggio, M., Dixit, V. D., Lauretani, F., Bandinelli, S., Senin, U., \& Ferrucci, L. (2006). Uric acid and inflammatory markers. 1174-1181. https://doi.org/10.1093/eurheartj/ehi879

Siemens. (2011). N Latex cystatin C. Siemens Healthcare Diagnostics Products GmbH.

Verdiansah. (2016). Pemeriksaan Fungsi Ginjal. CDK-237, 43(2), 148-154.

Yaswir, R., \& Maiyesi, A. (2012). Tinjauan Pustaka Pemeriksaan Laboratorium Cystatin C Untuk Uji Fungsi Ginjal. Jurnal Kesehatan Andalas, 1(1), 10-15. 